\title{
SISTEM MONITORING PIUTANG DAN INVENTORI BARANG DI PT. ANUGRAH CITRA PESTISINDO
}

\author{
${ }^{1}$ Tengku Khairil Ahsyar, ${ }^{2}$ Abd Rahman \\ ${ }^{1,2}$ Program Studi Sistem Informasi, Fakultas Sains dan Teknologi, UIN SUSKA Riau, \\ Jl. HR Soebrantas, KM. 18.5, No. 155, Simpang Baru, Pekanbaru, Indonesia, 28293. \\ Email: ${ }^{1}$ tengkukhairil@uin-suska.ac.id, ${ }^{2}$ abdrahman.0207@gmail.com
}

\begin{abstract}
ABSTRAK
PT. Anugrah Citra Pestisindo bergerak dalam bidang pemberi layanan yang terintegrasi dibidang jasa pemeliharaan kebersihan. Dalam transaksi bisnisnya, PT. Anugrah Citra Pestisindo menggunakan prinsip kerja dahulu sebelum menerima bayaran, hal ini biasa disebut piutang customer. Sedangkan untuk kegiatan pengerjaan jasanya, PT. Anugrah Citra Pestisindo memiliki gudang yang dijadikan sebagai tempat penyimpanan alat-alat kerjanya. Permasalahan yang di hadapi PT. Anugrah Citra Pestisindo saat ini yaitu pada pengolahan data piutang dan data inventori pada PT. Anugrah Citra Pestisindo yang masih dilakukan secara manual, yaitu dengan menggunakan buku besar dan arsip yang dilakukan dengan penulisan tangan. Penggunaan barang gudang oleh teknisi lapangan sering kali hanya mencatat dikertas kecil dan ditempelkan di halaman dinding. Bagian gudang juga harus memeriksa satu-persatu lembaran data yang ada untuk mengetahui keberadaan barang yang digunakan. Tujuan penelitian ini adalah untuk membangun sistem monitoring piutang dan inventori yang dapat mempermudah pihak perusahaan dalam mencatat, mendokumentasikan dan menjadikan data pada sistem ini untuk pengambilan keputusan kedepannya. Teknik perancangan sistem menggunakan metode Object Oriented Analysis Design (OOAD) dan model Unified Modelling Languange (UML), teknik pengujian sistem menggunakan teknik User Acceptance Testing (UAT) dengan hasil 100\% sistem berjalan dengan baik, dengan metode pengembangan sistem menggunakan metode waterfall dan analisa sistem menggunakan metode PIECES. Hasil penelitian ini adalah sebuah sitem monitoring piutang dan inventori.
\end{abstract}

Kata Kunci: OOAD, PIECES, PT. Anugrah Citra Pestisindo, sistem monitoring, UAT.

\section{A. PENDAHULUAN}

Dalam dunia bisnis, baik perusahaan yang baru tumbuh maupun yang telah berkembang, mulai menyadari pentingnya teknologi dalam mengembangkan usahanya. Pemanfaatan teknologi yang canggih sebagai pengganti tenaga kerja manusia serta perkembangan ilmu pengetahuan menjadi sarana dan prasarana oleh suatu perusahaan yang telah berkembang.

PT. Anugrah Citra Pestisindo bergerak dalam bidang pemberian layanan yang terintegrasi dibidang jasa pemeliharaan kebersihan. Dalam transaksi bisnisnya, PT. Anugrah Citra Pestisindo menggunakan prinsip kerja terlebih dahulu sebelum menerima bayaran. Hal ini biasa disebut piutang customer. Sedangkan untuk kegiatan pengerjaan jasanya, PT. Anugrah Citra Pestisindo memiliki gudang yang dijadikan sebagai tempat penyimpanan alat-alat kerjanya.

Pengolahan data piutang dan data inventori pada PT. Anugrah Citra Pestisindo masih dilakukan secara manual, yaitu dengan menggunakan buku besar dan pengarsipan dilakukan dengan cara manual ditulis dengan tangan. Pengelolaan seperti ini mengakibatkan kurang efisiennya pekerjaan yang dikerjakan, sehingga untuk mengontrol data-data membutuhkan waktu yang cukup lama.
Penggunaan barang gudang oleh teknisi lapangan sering kali hanya dicatat pada kertas kecil dan kemudian ditempelkan pada halaman dinding, bahkan ada pula yang menggunakan laporan secara lisan yang mengakibatkan laporan penggunaan barang gudang menjadi tidak jelas. Hal ini dikarenakan belum adanya sistem penunjang atau wadah yang dimiliki perusahaan dalam mencatat laporan penggunaan barang, sehingga bagian gudang harus memeriksa satu-persatu lembaran data yang ada untuk mengetahui keberadaan barang yang digunakan. Selain itu, permasalahan lain yakni sering terjadi kesalahan dalam penghitungan jumlah pemakaian barang gudang oleh teknisi lapangan, padahal untuk mengolah data barang perusahaan harus tepat dan teliti.

Demikian juga pada proses dokumentasi piutang. Pada proses pembayaran piutang customer masih menggunakan sistem berkas dengan penulisan tangan, hal ini menjadi salah satu penyebab terjadinya keterlambatan dalam pembuatan laporan dan tidak optimalnya pelayanan pada perusahaan. Piutang customer yang dikelola menggunakan buku besar dan arsip membuat pengontrolan data-data menjadi lambat dan membutuhkan waktu yang cukup lama.

Dalam mengelola data inventori dan piutang perusahaaan, telah banyak dilakukan penelitian sebelumnya. Sistem informasi monitoring data 
inventory Vio Hotel Indonesia merupakan sistem yang dapat mengontrol data inventori pada setiap cabang hotel. Dengan sistem ini pihak hotel dapat mengetahui status barang apakah baik, rusak, hilang atau sedang dipinjam [1]. Berikutnya sistem monitoring pembayaran piutang customer pada PT. LI [2] dan juga pernah dilakuan oleh [10]. Penelitian ini menghasilkan sebuah sistem yang dapat mengontrol pembayaran piutang yang dilakukan oleh pelanggan. Pada sistem ini perusahaan dapat membuat invoice langsung dari dalam sistem dan langsung terhubung ke data pelanggan. Hasil monitoring data piutang dapat dijadikan laporan data, baik pertahun, ataupun perbulan yang memberikan kemudahan dalam monitoring piutang.

Untuk mengatasi masalah di atas, penelitian ini membangun sistem aplikasi monitoring yang dikhususkan untuk mengelola data piutang dan data barang yang dapat membantu perusahaan dalam meningkatkan kinerja dalam siklus proses bisnisnya. Penelitian ini menggunakan Object Oriented Analysis Design (OOAD) dan dengan menggunakan tools Unified Modeling Language (UML). Selain itu, penelitian ini juga menggunakan metode PIECES untuk menganalisis sistem lama dan sistem yang akan diusulkan.

\section{B. LANDASAN TEORI}

\section{B.1. Monitoring}

Monitoring adalah pemantauan yang dapat dijelaskan sebagai kesadaran tentang apa yang ingin diketahui [1]. Pemantauan berkadar tingkat tinggi dilakukan agar dapat membuat pengukuran melalui waktu yang menunjukkan pergerakan ke arah tujuan atau menjauh dari itu. Monitoring juga merupakan penilaian yang terus menerus terhadap fungsi kegiatan-kegiatan proyek di dalam konteks jadwal-jadwal pelaksanaan dan terhadap penggunaan input-input proyek oleh kelompok sasaran di dalam konteks harapan-harapan rancangan [3].

\section{B.2. Inventori}

Inventori meliputi semua barang yang dimiliki oleh perusahaan dengan tujuan dikonsumsikan dalam siklus operasi normal perusahaan sebagai barang yang dimiliki. Semua barang yang berwujud dapat disebut sebagai inventori tergantung dari sifat dan jenis usaha perusahaan. Secara umum, inventori merupakan suatu aset yang ada dalam bentuk barang-barang yang dimiliki oleh perusahaan [1].

\section{B.3. Piutang}

Pembayaran piutang customer merupakan kegiatan yang sangat penting untuk kelancaran kegiatan arus kas perusahaan. Tanpa adanya pembayaran piutang yang baik maka keuangan perusahaan tidak akan berjalan sebagaimana yang diharapkan, sehingga akan menghambat segala aktifitas dan pelaksanaan kegiatan kerja [2]. Piutang timbul ketika sebuah perusahaan menjual barang atau jasa secara kredit dan berhak atas penerimaan kas di masa mendatang. Piutang juga dapat timbul ketika perusahaan memberikan pinjaman uang kepada perusahaan lain, melakukan suatu jasa atau transaksi lain yang menciptakan suatu hubungan dimana satu pihak berutang kepada yang lain.

\section{B.4. Object Oriented Analysis and Design}

Object Oriented Analysis adalah metode analisa yang memeriksa requirement (syarat/keperluan yang harus dipenuhi suatu sistem) dari sudut pandang kelas-kelas dan objekobjek yang ditemui dalam ruang lingkup permasalahan. Sedangkan Object Oriented Design adalah metode untuk mengarahkan arsitektur software yang didasarkan pada manipulasi objekobjek sistem atau subsistem $[4,6]$.

\section{B.5. Unified Modeling Language (UML)}

Unified Modeling Language adalah sebuah standar bahasa yang banyak digunakan di dunia industri untuk mendefinisikan kebutuhan, membuat analisis dan desain, serta menggambarkan arsitektur dalam pemrograman berorientasi objek [5].

\section{B.6. Database}

Database merupakan kumpulan data yang terintegrasi dan diatur sedemikian rupa sehingga data dapat dimanipulasi, diambil, dan dicari secara cepat [7]. Menurut [8], database adalah sekumpulan tabel-tabel yang saling berelasi. Relasi tersebut bisa ditunjukkan dengan kunci dari tiap tabel yang ada. Satu database menunjukkan satu kumpulan data yang dipakai dalam satu lingkup perusahaan atau instansi.

\section{B.7. User Acceptance Testing (UAT)}

User Acceptance Testing yaitu pengujian yang dilakukan oleh pengguna dari sistem untuk memastikan fungsi- fungsi yang ada pada sistem tersebut telah berjalan dengan baik dan sesuai dengan kebutuhan pengguna [9].

\section{METODOLOGI PENELITIAN \\ C.1. Perencanaan}

Identifikasi masalah dilakukan pada tahap ini. Hal ini dilakukan untuk mengidentifikasi masalah dan kebutuhan pengguna. Untuk mendapatkan data primer dan data skunder dilakukan proses wawancara dan observasi. Wawancara dilakukan ke Kepala Marketing PT. Anugrah Citra Pestisindo. Sedangkan observasi dilakukan untuk mengetahui gambaran real yang ada pada gudang PT. Anugrah Citra Pestisindo khususnya pada gudang tersebut. 


\section{C.2. Analisa dan Perancangan}

Pada tahap analisa dan perancangan sistem ini, dilakukan analisa sistem usulan dan perancangan sistem. Analisa sistem yang sedang berjalan dilakukan dengan cara menganalisis hasil wawancara dan observasi serta dokumen-dokumen yang telah didapatkan pada tahap perencanaan. Proses berikutnya melakukan perbandingan antara sistem lama dengan sistem baru secara Performance, Information, Economic, Control, Eviciency, dan Service menggunakan metode PIECES (Tabel 1 merupakan hasil perbandingan antara sistem lama dengan sistem baru). Sedangkan pada analisa sistem usulan menggunakan pendekatan OOAD dengan tools UML yang melibatkan usecase diagram, squence diagram, activity diagram, class diagram, perancangan database, serta perancangan antarmuka sistem.

\section{C.3. Implementasi dan Pengujian}

Lingkungan implementasi pada penelitian ini diantaranya sebagai berikut:

(1) Spesifikasi minimum perangkat keras

(a) Processor Intel Dual Core $2.6 \mathrm{Ghz}$

(b) Memory RAM DDR2 V-gen $2 \mathrm{~Gb}$

(c) Hardisk $80 \mathrm{~Gb}$ Seagate/Samsung SATA

(d) Monitor LG/Samsung Wide Screen 17"

(2) Spesifikasi minimum perangkat lunak

(a) Sistem Operasi Windows XP atau 7

(b) Web Browser Firefox, Google Chrome atau Internet Explorer.

(c) Bahasa pemrograman PHP.

(d) Database MySQL dengan interface PHPMyAdmin.

Sedangkan pada pengujian sistem menggunakan metode User Acceptance Test (UAT) pada konteks penerimaan sistem oleh pihak terkait berdasarkan requirement yang telah disetujui.

\section{ANALISA DAN PERANCANGAN}

\section{D.1. Analisa Sistem yang Sedang Berjalan}

Pada proses penggunaan barang gudang oleh teknisi dimulai dari teknisi mengambil barang atau alat kerja sesuai dengan pekerjaan pada hari tersebut, kemudian mencatat barang dan obat pada kertas kecil yang nantinya ditempelkan pada sebuah Majalah Dinding (Mading) yang terdapat pada gudang tersebut. Proses berikutnya, admin gudang mencatat data penggunaan barang yang ada pada mading tersebut. Sedangkan pada proses pembuatan invoice untuk pelanggan, dibuat dengan menggunakan Microsoft Excel yang kemudian dicetak lalu diberikan atau diantarkan kepada pelanggan. Setelah pembayaran invoice dilakukan oleh pelanggan, data direkap dan dicatat pada sebuah buku besar. Untuk dapat melihat prosesproses yang dilakukan secara manual, dapat dilihat pada Tabel 1 pada kolom Sistem Lama.
Dari permasalahan tersebut, dilakukan perbandingan antara proses-proses manual (sistem manual) dengan proses yang dilakukan setelah sistem dibangun. Untuk membandingkan kedua proses tersebut, digunakan metode PIECES untuk dapat secara detail melihat dari sisi Performance, Information, Economic, Control, Eviciency, dan Service. Tabel 1 merupakan hasil perbandingan antara sistem manual dengan sistem baru.

Tabel 1. Perbandingan sistem lama dengan baru

\begin{tabular}{|c|c|c|}
\hline Jenis Analisis & Sistem Lama & Sistem Baru \\
\hline Performance & $\begin{array}{l}\text { Proses } \\
\text { pengumpulan data } \\
\text { penggunaan } \\
\text { inventori oleh } \\
\text { teknisi tidak } \\
\text { realtime. }\end{array}$ & $\begin{array}{l}\text { Proses pencatatan } \\
\text { data penggunaan } \\
\text { inventori lebih cepat } \\
\text { karena berbasih } \\
\text { komputer dengan } \\
\text { menggunakan } \\
\text { perangkat lunak } \\
\text { untuk proses } \\
\text { pengolahan data } \\
\text { secara otomatis. }\end{array}$ \\
\hline Information & $\begin{array}{l}\text { Informasi dapat } \\
\text { dengan mudah di } \\
\text { salah gunakan. } \\
\text { Tidak akurat } \\
\text { dalam pencatatan } \\
\text { penggunaan } \\
\text { barang gudang. }\end{array}$ & $\begin{array}{l}\text { Kemudahan dalam } \\
\text { pencatan data } \\
\text { pengguaan barang, } \\
\text { data aman, mudah } \\
\text { disimpan dan dapat } \\
\text { diakses kapan saja. }\end{array}$ \\
\hline Economic & $\begin{array}{l}\text { Pengguaan kertas, } \\
\text { tinta dan alat tulis } \\
\text { lainnya unttuk } \\
\text { penyimpanan } \\
\text { dokumen dan } \\
\text { pencatatan pada } \\
\text { mading. Jika } \\
\text { terjadi kesalahan } \\
\text { tidak dapat } \\
\text { digunakan lagi. } \\
\end{array}$ & $\begin{array}{l}\text { Dengan sistem } \\
\text { komputerisasi akan } \\
\text { menghemat waktu } \\
\text { dan kertas, alat tulis } \\
\text { atau perlengkapan } \\
\text { penyimpanan } \\
\text { dokumen. Jika } \\
\text { terjadi kesalahan } \\
\text { masih bisa diedit. }\end{array}$ \\
\hline Control & $\begin{array}{l}\text { Sistem pencatatan } \\
\text { data penggunaan } \\
\text { barang masih } \\
\text { manual akan sulit } \\
\text { melakukan kontrol } \\
\text { karena } \\
\text { pemrosesan data } \\
\text { dilakukan oleh } \\
\text { manusia dan } \\
\text { kemungkinan } \\
\text { terjadi kesalahan } \\
\text { sangat besar. }\end{array}$ & $\begin{array}{l}\text { Sistem berbasis } \\
\text { komputer akan } \\
\text { memudahkan } \\
\text { kontrol sehingga } \\
\text { kemungkinan } \\
\text { terjadinya kesalahan } \\
\text { dapat dikurangi. }\end{array}$ \\
\hline Eviciency & $\begin{array}{l}\text { Tidak efisiennya } \\
\text { pencatan } \\
\text { penggunaan } \\
\text { barang gudang } \\
\text { dan penyimpanan } \\
\text { berkas invoice. } \\
\end{array}$ & $\begin{array}{l}\text { Lebih cepat dan } \\
\text { lebih efisien karena } \\
\text { data gudang dan } \\
\text { data piutang sudah } \\
\text { terkomputerisasi. }\end{array}$ \\
\hline Services & $\begin{array}{l}\text { Pencarian data } \\
\text { harus melihat } \\
\text { pada buku besar, } \\
\text { dan mencari } \\
\text { dokumen invoice } \\
\text { satu persatu }\end{array}$ & $\begin{array}{l}\text { Pencarian data dapat } \\
\text { dilakukan dengan } \\
\text { cepat dan sudah } \\
\text { terkomputerisasi. }\end{array}$ \\
\hline
\end{tabular}

\section{D.2. Analisa Sistem Usulan}

Sistem yang dibangun hanya dapat digunakan pada lingkungan internal yang ada pada PT. Anugrah Citra Pestisindo. Melalui sistem ini pengguna dapat: (1) mengolah dan menyeleksi data piutang customer dan inventori barang perusahaan; 
(2) mendapatkan laporan pembayaran piutang baik secara bulanan maupun tahunan, inventori, data suplier, pembelian, retur pembelian dan pemakaian; (3) melakukan pengecekan penggunaan inventori, daftar suplier, daftar return barang, dan daftar pembelian.

Sistem usulan yang dibangun pada PT. Anugrah Citra Pestisindo ini berbasis web dengan menggunakan bahasa pemrograman PHP dan database MySQL. Sistem ini akan menghubungkan 3 orang pengguna sistem yakni Administrator, Admin Gudang dan Accounting. Kebutuhan fungsional sistem dapat dilihat pada usecase diagram yang terdapat pada Gambar 1. Sedangkan aliran data dari masing-masing usecase yang ada telah digambarkan pada squence diagram. Untuk melihat salah satu squence diagram dari usecase yang telah dibangun, dapat dilihat pada Gambar 2. Gambar 2 merupakan squence diagram untuk Admin Gudang.

\section{D.3. Perancangan Sistem}

Menu yang dirancang ada pada sistem terdiri dari 3 hak askses pengguna, yakni: (1) Administrator; (2) Admin Gudang; (3) Accounting. Pada hak akases Administrator, terdapat 4 menu yang ditampilkan pada sistem. Sedangkan pada Admin Gudang terdapat 12 menu yang nantinya menjadi navigasi dalam memperlancar proses kinerja yang ada di gudang. Selanjutnya terdapat 11 menu yang ada pada hak akses Accounting yang di buat untuk menangani kinerja bidang akunting terutama pada piutang. Untuk melihat perancangan menu dapat merujuk pada Gambar 3.

Pada sistem monitoring piutang dan inventori barang ini, terdapat 11 class pada perancangan class diagram-nya. Untuk melihat secara rinci hasil perancangan class diagram beserta atribut yang melekat pada class tersebut, dapat dilihat pada Gambar 4.

Selain dari perancangan class diagram, perancangan antarmuka sistem dibuat untuk memudahkan dalam membangun sistem. Perancangan sistem yang dibuat berdasarkan pada kebutuhan sistem dan dibantu dengan menggunakan tabel deskripsi perancangan sistem seperti yang terdapat pada Tabel 2 yang merupakan salah satu tabel deskripsi perancangan antarmuka sistem. Sedangkan hasil perancangan antarmuka sistem, dapat dilihat pada Gambar 5 yang merupakan salah satu hasil perancangan antarmuka sistem untuk bagian input pemakaian barang inventori.

Tabel 2. Deskripsi antarmuka input pemakaian barang inventori

\begin{tabular}{|c|c|c|}
\hline No & Nama & Keterangan \\
\hline 1 & Logo Perusahaan & $\begin{array}{l}\text { Ukuran height: 35px; width: } \\
\text { 100px. }\end{array}$ \\
\hline 2 & $\begin{array}{l}\text { Ucapan selamat } \\
\text { datang }\end{array}$ & $\begin{array}{l}\text { a. Tata letak center. } \\
\text { b. Jenis tulisan Source Sans } \\
\text { Pro. } \\
\text { c. Ukuran tulisan 14px. } \\
\text { d. Warna tulisan \#FFF. } \\
\text { e. Khusus warna tulisan } \\
\text { "logout" yellow. }\end{array}$ \\
\hline 3 & Konten Header & $\begin{array}{l}\text { a. Jenis tulisan Source Sans } \\
\text { Pro. } \\
\text { b. Ukuran tulisan } 15 \mathrm{px} \text {. } \\
\text { c. Warna tulisan \#333. }\end{array}$ \\
\hline 4 & $\begin{array}{l}\text { Judul } \\
\text { "Pemakaian" }\end{array}$ & $\begin{array}{l}\text { a. Jenis tulisan Source Sans } \\
\text { Pro. } \\
\text { b. Warna tulisan \#333. } \\
\text { c. Ukuran tulisan h3. }\end{array}$ \\
\hline 5 & $\begin{array}{l}\text { Button Input } \\
\text { Pemakaian Baru }\end{array}$ & $\begin{array}{l}\text { a. Background color \#3c8dbc. } \\
\text { b. Jenis tulisan Source Sans } \\
\text { Pro. } \\
\text { c. Warna tulisan \#fff. }\end{array}$ \\
\hline 6 & Combo box & $\begin{array}{l}\text { a. Background color white. } \\
\text { b. Panjang combo box } 75 \mathrm{px} \text {. }\end{array}$ \\
\hline 7 & $\begin{array}{l}\text { Keterangan } \\
\text { Combo box }\end{array}$ & $\begin{array}{l}\text { a. Warna tulisan \#333. } \\
\text { b. Jenis tulisan Source Sans } \\
\text { Pro. } \\
\text { c. Ukuran tulisan } 14 \mathrm{px} \text {. }\end{array}$ \\
\hline 8 & $\begin{array}{l}\text { Search dan search } \\
\text { box }\end{array}$ & $\begin{array}{l}\text { a. Warna tulisan \#333. } \\
\text { b. Jenis tulisan Source Sans } \\
\text { Pro. } \\
\text { c. Ukuran tulisan } 14 \mathrm{px} \text {. } \\
\text { d. Background color white }\end{array}$ \\
\hline 9 & Judul Tabel & $\begin{array}{l}\text { a. Warna tulisan \#333. } \\
\text { b. Jenis tulisan Source Sans } \\
\text { Pro. } \\
\text { c. Ukuran tulisan } 14 \mathrm{px} \text {. }\end{array}$ \\
\hline 10 & $\begin{array}{l}\text { Keterangan bawah } \\
\text { tabel }\end{array}$ & $\begin{array}{l}\text { a. Warna tulisan \#333. } \\
\text { b. Jenis tulisan Source Sans } \\
\text { Pro. } \\
\text { c. Ukuran tulisan } 14 \mathrm{px} \text {. }\end{array}$ \\
\hline 11 & Tabel & $\begin{array}{l}\text { a. Tata letak center. } \\
\text { b. Ukuran } 812 \text { px. }\end{array}$ \\
\hline 12 & $\begin{array}{l}\text { Button Previous } \\
\text { dan Next }\end{array}$ & $\begin{array}{l}\text { a. Warna tulisan \#333. } \\
\text { b. Jenis tulisan Source Sans } \\
\text { Pro. } \\
\text { c. Ukuran tulisan } 14 \mathrm{px} \text {. }\end{array}$ \\
\hline
\end{tabular}




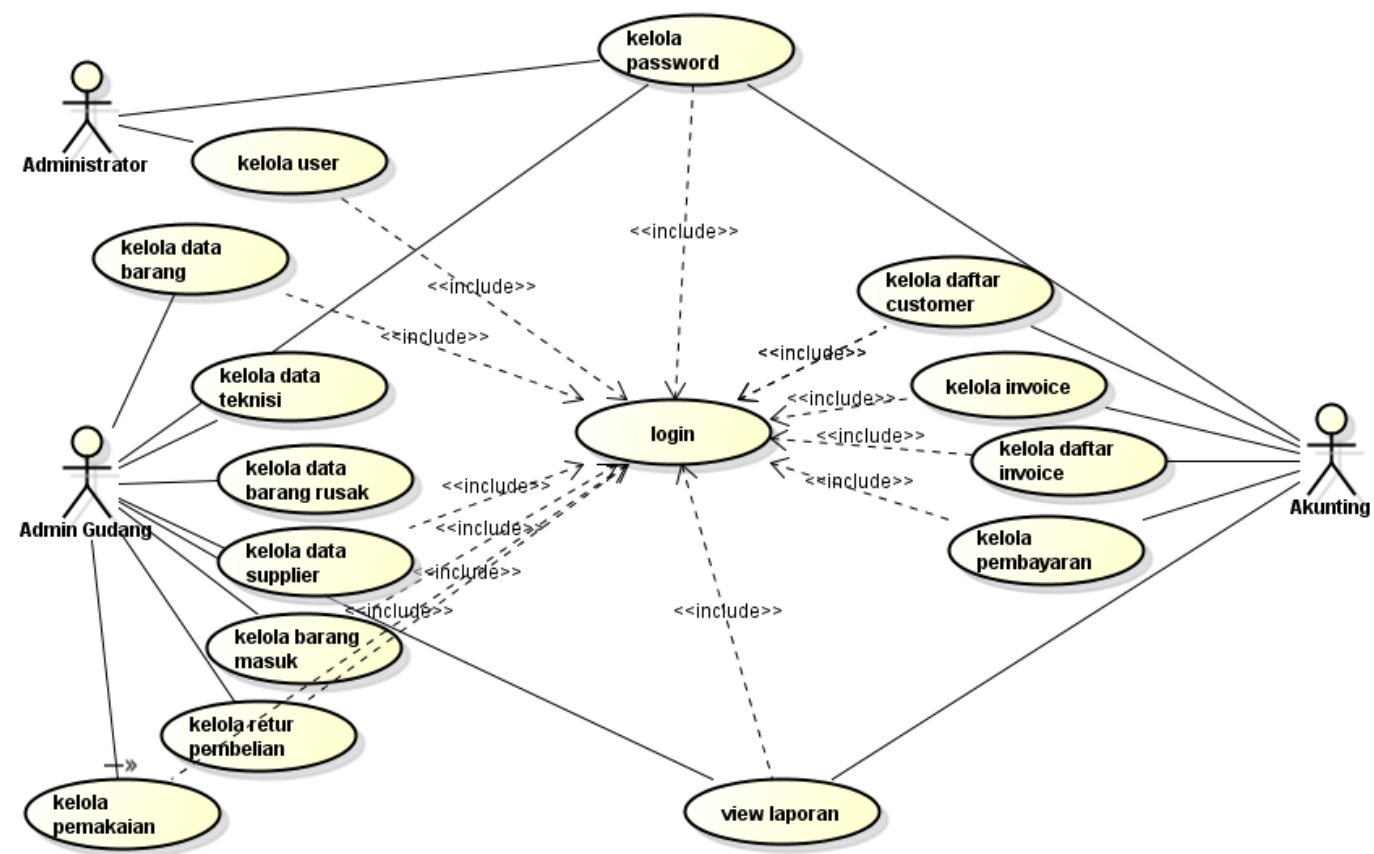

Gambar 1. Usecase sistem usulan

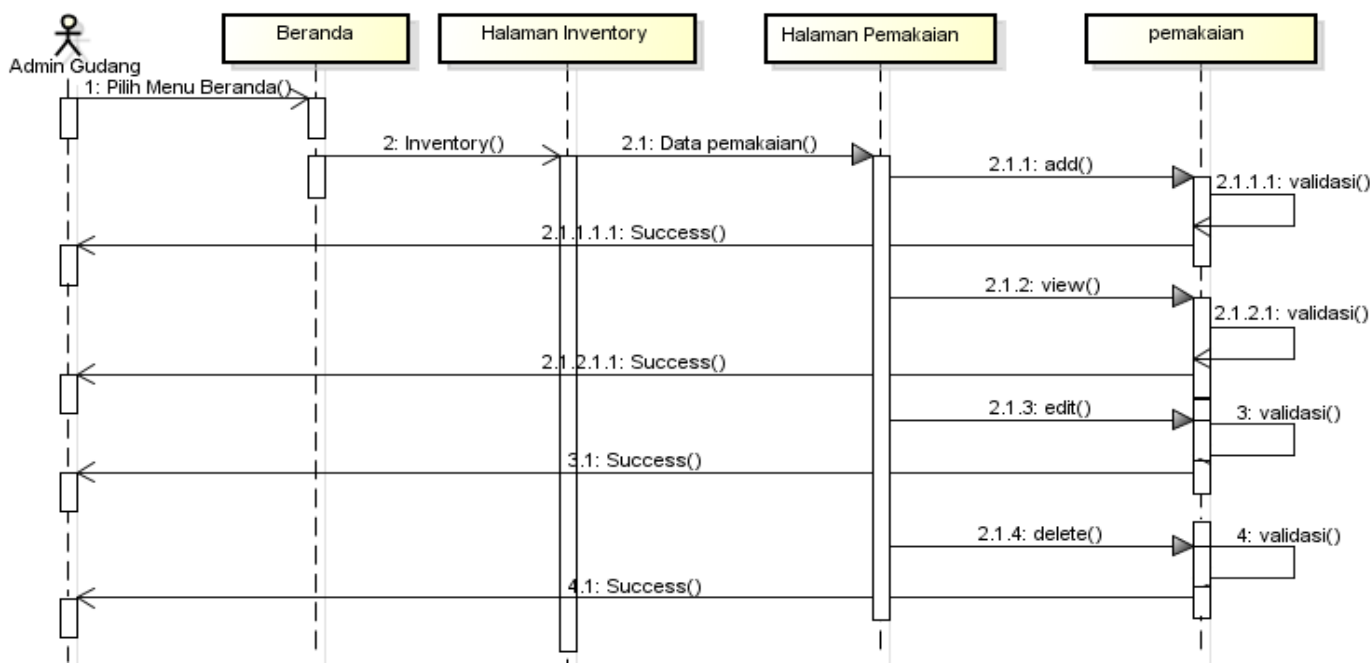

Gambar 2. Squence diagaram admin gudang

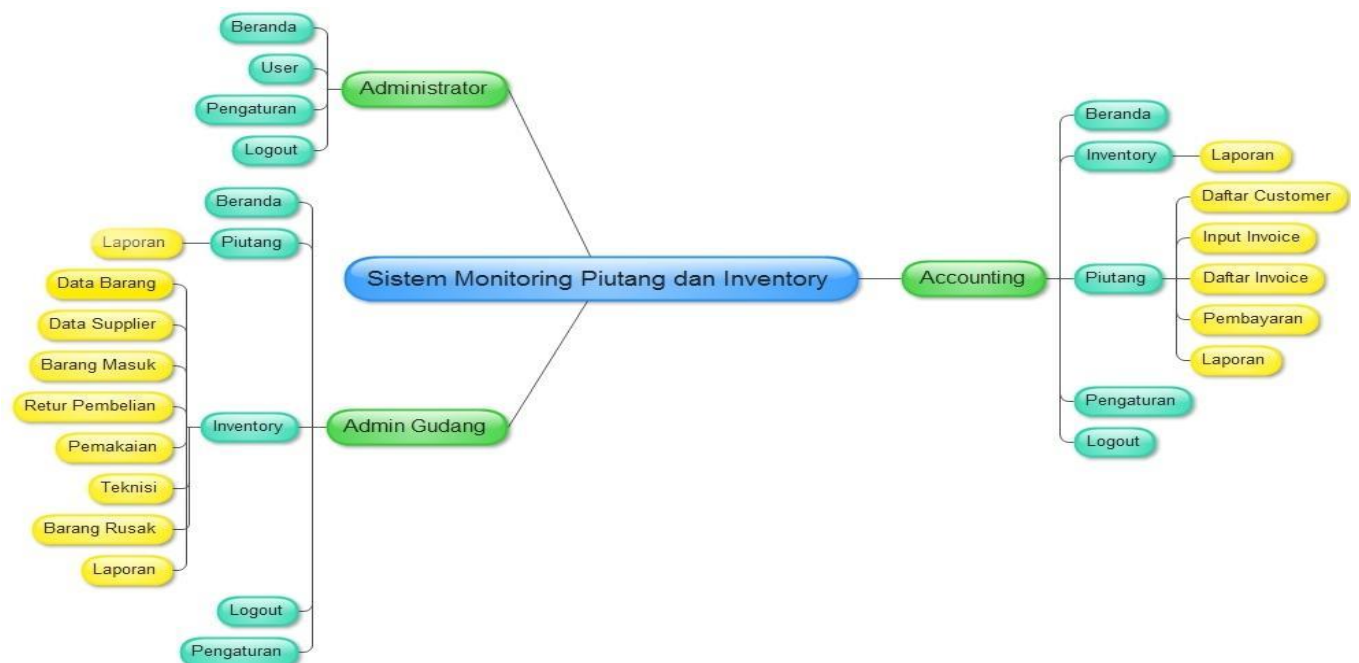

Gambar 3. Perancangan menu sistem monitoring piutang dan inventory 


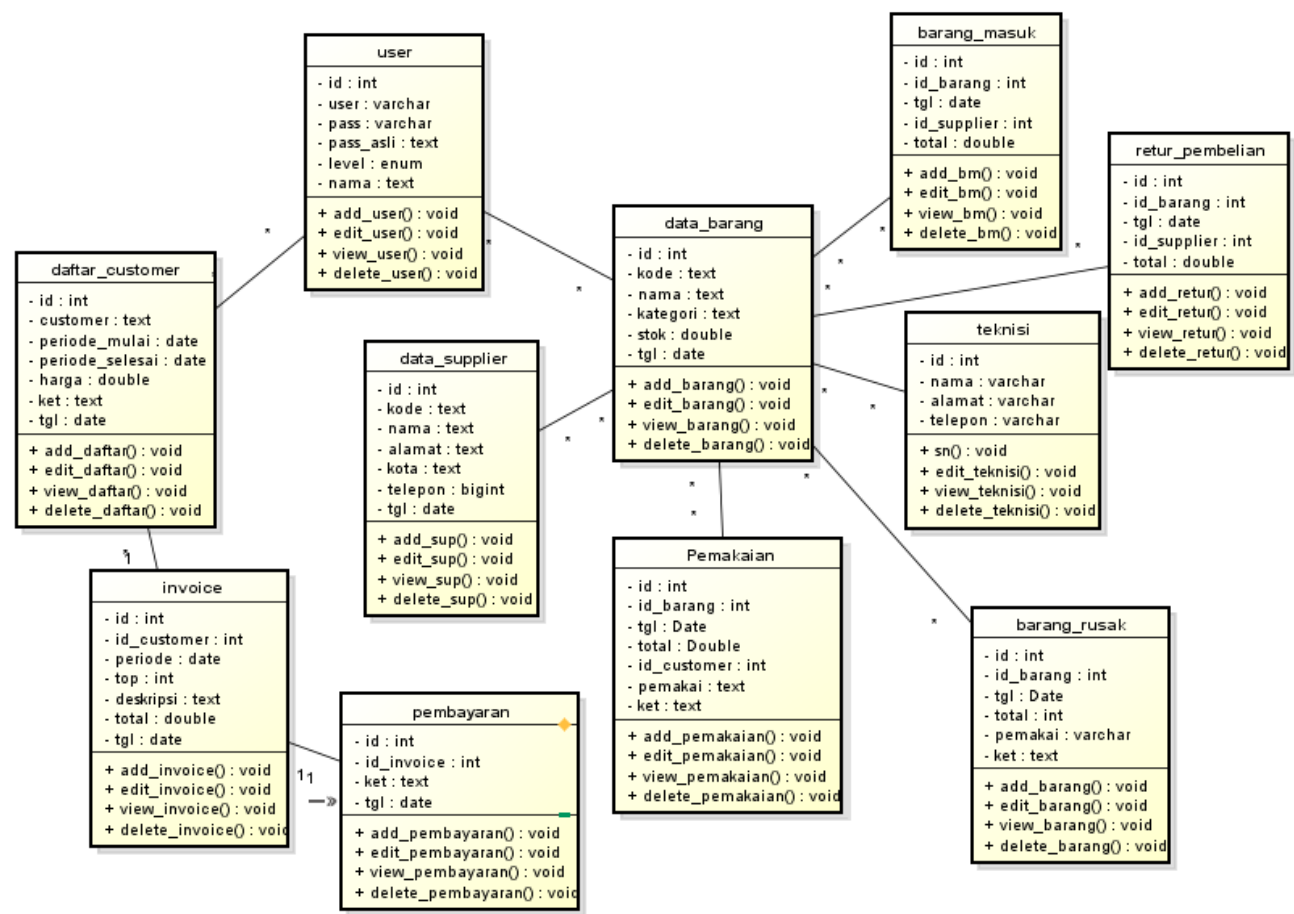

Gambar 4. Class diagram

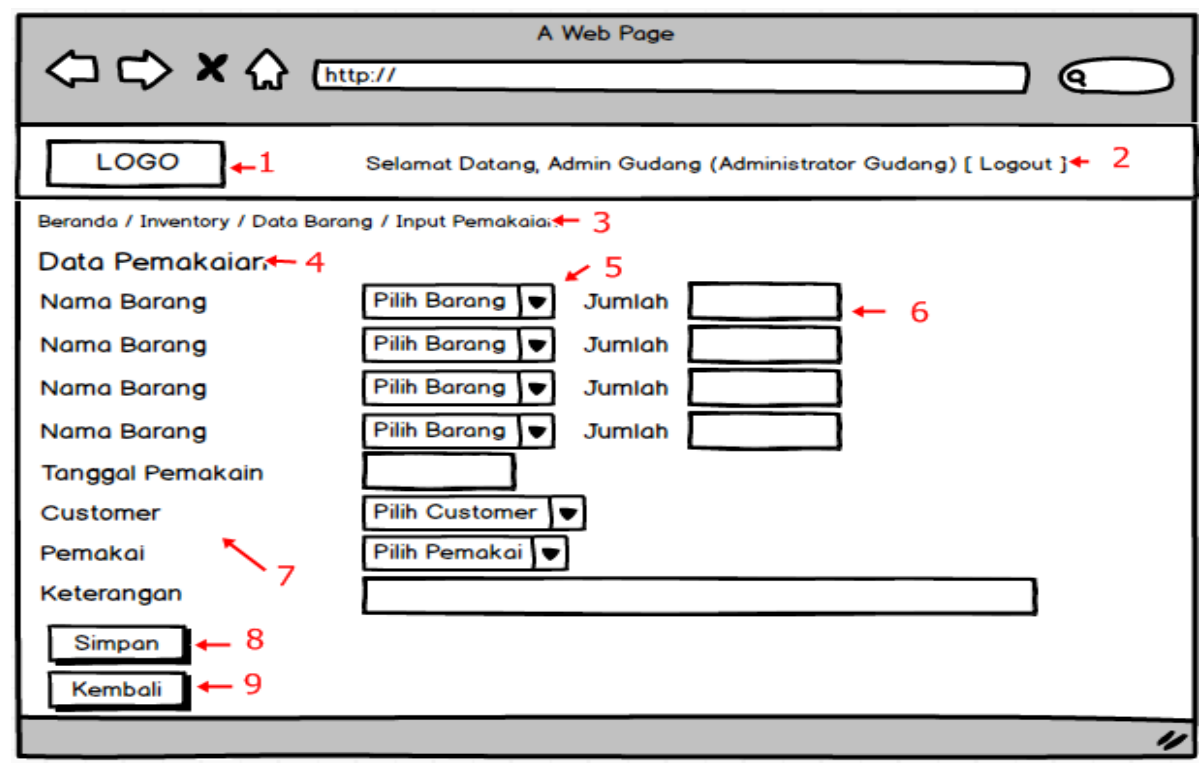

Gambar 5. Perancangan antarmuka sistem

\section{E. HASIL IMPLEMANTASI DAN PENGUJIAN}

\section{E.1. Hasil Implementasi}

Tampilan menu sistem informasi monitoring ini terbagi menjadi 3 hak akses, yaitu: (1) Administrator, yang memiliki hak akses untuk masuk sebagai administrator yang dapat melakukan pengaturan dan pengelolaan pengguna sistem; (2) Admin Gudang, memiliki akses sebagai admin gudang yang terdaftar dalam database yang dapat melakukan proses pengelolaan data barang, suplier, retur pembelian, pemakaian barang, teknisi, barang rusak, dan laporan; serta (3) Accounting, yang memiliki hak akses sebagai akunting yang dapat melakukan proses piutang dan inventori seperti: (1) pengelolaan data yang berhubungan dengan customer; (2) invoice; (3) pembayaran; dan (4) pengelolaan laporan..

Gambar 6 merupakan halaman tampilan awal antarmuka sistem monitoring pada PT. Anugrah Citra Pestisindo. Halaman ini digunakan oleh masing-masing pengguna untuk masuk ke sistem. Pada tampilan halaman ini, terdapat logo perusahaan yang melambangkan identitas dari sistem, form pengisian username dan form pengisian password, serta tombol login. Setiap pengguna yang ingin masuk sesuai dengan hak 
akses yang telah dimiliki harus melalui proses login melalui tampilan ini.

Gambar 7 merupakan halaman utama sistem monitoring yang terdiri dari 2 kelompok menu utama dan 1 menu ubah password. Adapun 2 kelompok menu utama tersebut yakni fitur piutang dan fitur inventori. Kedua fitur utama ini samasama dimiliki oleh pengguna Admin Gudang dan Accounting. Namun secara detail, terdapat perbedaan pada fitur yang ada di dalam masingmasing menu utama tersebut. Untuk pengguna Admin Gudang, menu utama piutang hanya terdapat sebuah halaman laporan. Sedangkan pada menu inventori, terdapat 6 fitur yang terdiri dari data barang, data suplier, barang masuk, retur pembelian, pemakaian dan laporan. Hal ini berbeda dengan hak akses Accounting. Pada menu inventori hanya terdapat halaman laporan, sedangkan pada menu piutang terdapat 5 fitur yang diantaranya terdiri dari: data customer, input invoice, daftar invoice, pembayaran, dan laporan. Selain dari fiturfitur di atas, kedua-duanya terdapat menu pengaturan yang berhubungan dengan pengelolaan password pengguna.

Untuk halaman inventori barang, terdapat delapan kotak menu yang dibuat dengan menggunakan icon. Diantaranya data barang, pemakaian, data suplier, barang masuk, retur pembelian, laporan harian, laporan bulanan, dan laporan tahunan. Untuk lebih jelasnya dapat dilihat pada Gambar 8. Pada halaman ini pengguna dapat mengakses salah satu icon tersebut untuk melakukan proses yang berhubungan dengan inventori barang. Sebagai contoh pada menu data barang. Pada menu tersebut menghubungkan ke halaman pengolahan data yang berhubungan dengan barang-barang yang ada digudang. Hal ini memudahkan pengguna (Admin Gudang) dalam mengelola barang-barang yang selama ini dilakukan secara manual. Pada Gambar 9 dapat dilihat tampilan daftar barang yang ada di gudang. Pada tampilan tersebut terdapat sebuah tabel yang terdiri dari tujuh buah kolom dimana terdiri dari No, Kode, Nama, Kategori, Stok, Tanggal Input Barang, dan Opsi. Pada tabel ini, kita Admin Gudang dapat melihat daftar barang seperti nama barang, kategori barang, kode yang diterapkan, jumlah stok yang masih tersedia, dan kapan barang tersebut di input ke dalam sistem. Selain itu, pihak admin gudang juga dapat mengubah dan menghapus barang melalui menu yang tersedia pada kolom 7. Halaman ini juga dimudahkan dengan disediakannya link halaman jika ingin melihat daftar barang lain yang tidak terlihat pada tampilan tersebut, karena pada Gambar 10 daftar tersebut hanya dibatasi dengan 10 daftar barang. Untuk menampilkan tampilan yang lebih dari sepuluh daftar, dapat memilih menu yang berada di atas kiri tabel yakni pada menu "record per page". Selain itu, untuk memudahkan pencarian daftar barang yang lebih cepat, dapat menggunakan fasilitas pencarian yang disediakan pada sudut kanan atas tabel barang tersebut. Hal ini tentunya dapat mempercepat proses pencarian jika dibandingkan dengan cara manual yang biasa dilakukan sebelum adanya sistem.

Selain dari halaman inventory barang, terdapat pula halaman lain seperti halaman untuk monitoring piutang yang terdiri dari tujuh buah menu berbasis icon yang terdiri dari data customer, input invoice, daftar invoice, laporan harian, laporan bulanan, laporan tahunan, dan pembayaran. Pada tampilan ini, pengguna khusus Accounting dapat mengakses beberapa halaman seperti data dan informasi yang berhubungan dengan customer, invoice, dan laporan yang bersifat harian, bulanan dan tahunan, serta yang berhubungan dengan proses pembayaran. Gambar 10 merupakan halaman contoh untuk mencetak invoice.

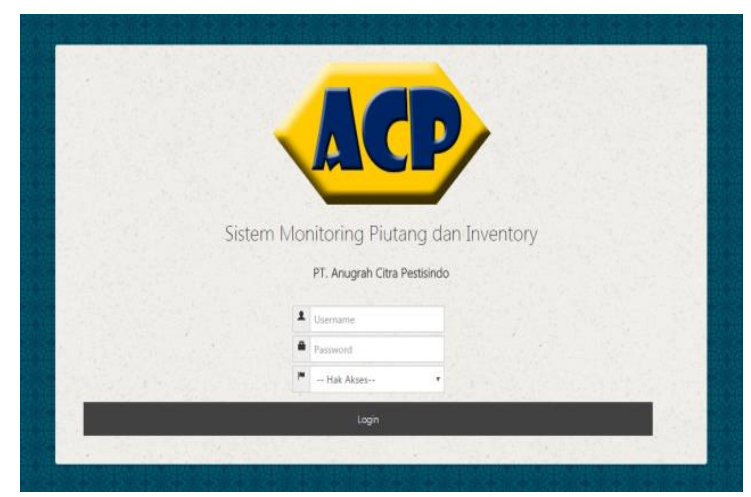

Gambar 6. Halman awal sistem

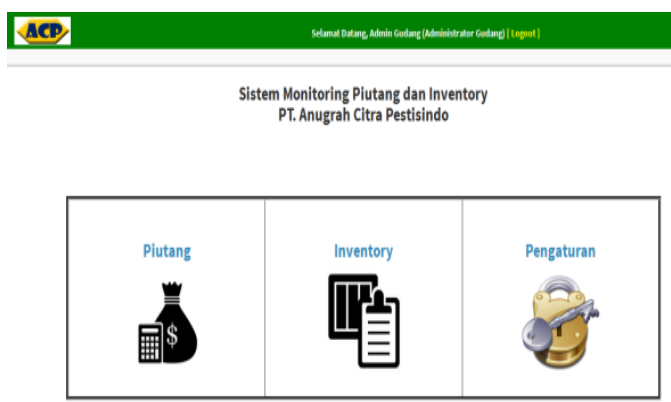

Gambar 7. Halaman awal hak akses Accounting
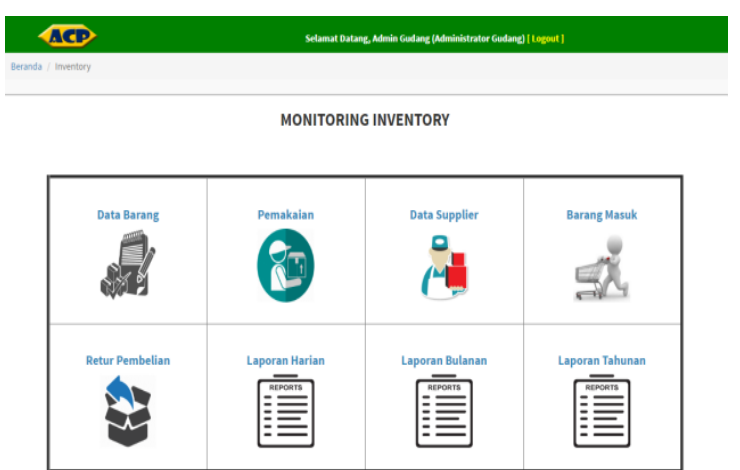

Gambar 8. Halaman monitoring inventori barang 


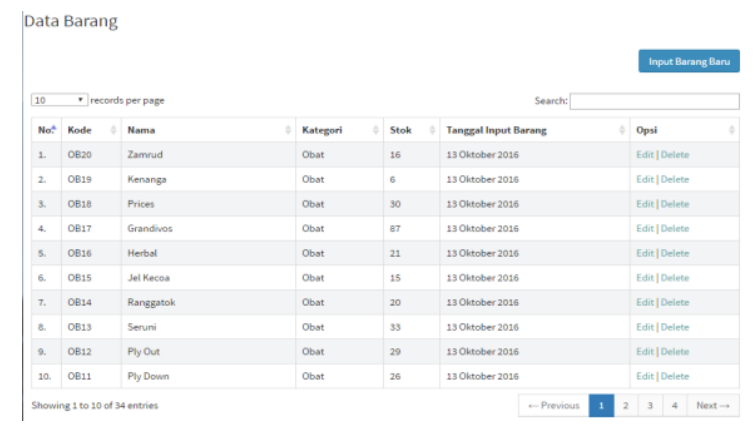

Gambar 9. Halaman data barang

\section{E.2. Hasil Pengujian}

Hasil pengujian pada sistem ini menunjukkan bahwa fitur-fitur sistem yang ada dapat berjalan dengan baik. Hal ini dibuktikan dari hasil pengujian dengan menggunakan metode User Acceptance Test (UAT) dengan nilai $100 \%$. Terdapat tujuh kriteria penting yang di uji diantaranya seperti: kinerja sistem, akses ke fitur, kesalahan dalam menampilkan data, penggunaan sistem oleh pengguna, bentuk disain sistem, kelancaran sistem, dan tampilan dari menu sistem. Dari tujuh uraian pertanyaan yang disuguhkan kepada pengguna sistem, semua kriteria tersebut dapat diterima.

Tabel 3. Tabel hasil pengujian UAT

\begin{tabular}{lcc}
\hline \multicolumn{1}{c}{ Uraian Pertanaan } & \multicolumn{2}{c}{ Hasil } \\
\cline { 2 - 3 } & Berhasil & $\begin{array}{c}\text { Tidak } \\
\text { Berhasil }\end{array}$ \\
\hline $\begin{array}{l}\text { Bagaimana kinerja sistem? } \\
\text { Apakah semua fitur dapat diakses } \\
\text { dengan baik? }\end{array}$ & $\sqrt{ }$ \\
$\begin{array}{l}\text { Apakah terjadi kesalahan dalam } \\
\text { menampilkan data ataupun dalam } \\
\text { penginputan data? }\end{array}$ & $\sqrt{ }$ \\
$\begin{array}{l}\text { Apakah user dapat menggunakan } \\
\text { dengan baik? }\end{array}$ & $\sqrt{ }$ \\
$\begin{array}{l}\text { Bagaimana bentuk dari desain } \\
\text { sistem? }\end{array}$ & $\sqrt{ }$ \\
$\begin{array}{l}\text { Apakah sistem dapat berjalan } \\
\text { lancar? }\end{array}$ & $\sqrt{ }$ \\
$\begin{array}{l}\text { Bagaimana tampilan menu } \\
\text { sistem? }\end{array}$ & $\sqrt{ }$
\end{tabular}

\section{F. KESIMPULAN}

Berdasarkan tahapan penelitian yang telah dilakukan, dapat diambil kesimpulan: (1) Berdasarkan hasil uji yang telah dilakukan dengan menggunakan metode UAT menunjukkan bahwa sistem monitoring piutang dan inventori pada PT. Anugrah Citra Pestisindo berhasil memenuhi kebutuhan fungsional; (2) Sistem monitoring piutang dan inventori yang telah dibangun dapat direkomendasikan untuk dapat diterapkan sebagai

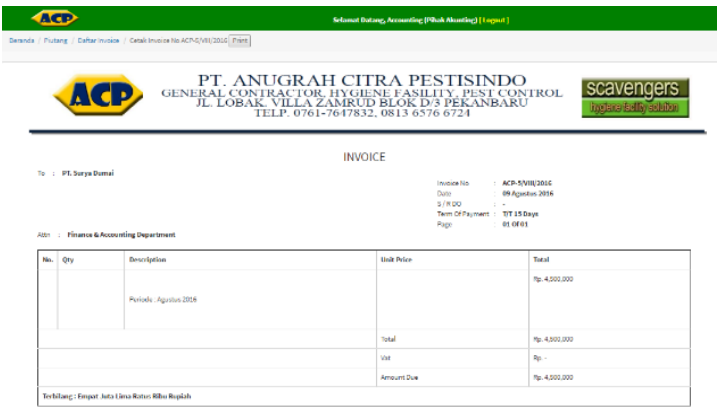

Gambar 10. Halaman cetak invoice

sistem baru yang dapat membantu perusahaan dalam mengolah data piutang customer dan inventori perusahaan.

\section{REFERENSI}

[1] Rohayati, Mita. 2014. Membangun Sistem Informasi Monitoring Data Inventory Di Vio Hotel Indonesia. Jurnal Ilmiah Komputer dan Informatika (KOMPUTA). ISSN 2089-9033, Vol 1.

[2] Aisyah, Euis Siti Nur dkk. 2015. Sistem Monitoring Pembayaran Piutang Customer Pada PT. LI. Prosiding Nasional Sistem dan Informatika. ISSN: 2460-8378.

[3] Mudjahidin, dan Putra, Nyoman Dita Pahang Putra. 2010. Rancang Bangun Sistem Informasi Monitoring Perkembangan Proyek Berbasis Web Studi Kasus di Dinas Bina Marga dan Pemantusan. Jurnal Teknik Industri, Vol. 11, No. 1.

[4] Nugroho, Adi. 2010. Analisis dan Perancangan Sistem Informasi dengan Metode Berorientasi Objek. Informatika, Bandung.

[5] Suhendar, A, dan Gunadi, H. 2002. Visual Modelling Menggunakan UML dan Rational Rose.Informatika, Bandung.

[6] Salahuddin, M, dan A.S, Rosa. 2013. Rekayasa Perangkat Lunak Terstruktur dan Berorientasi Objek. Informatika, Bandung.

[7] Raharjo, B. 2011. Belajar Otodidak Membuat Database Menggunakan MySQL. Informatika, Bandung.

[8] Fadlisyah, A. 2008. Pemrograman Database Konsep dan Implementasi. Graha Ilmu, Yogyakarta.

[9] Zarnelly, dan Adelia, Della. 2014. Rancang Bangun Media Pelayanan Umum Desk Info Di Pengadilan Tinggi Agama Pekanbaru. Jurnal Informatika. ISSN 2502-8995, Vol.14, No.1.

[10] Aprisa, dan Monalisa, Siti. 2015. Rancang Bangun Sistem Informasi Monitoring Perkembangan Proyek Berbasis Web (Studi Kasus: PT. Inti Pratama Semesta)," Jurnal Rekayasa dan Manajemen Sistem Informasi. ISSN: 2460-8181, Vol. 1, No. 1. 